Factors affecting ENMs toxicity towards terrestrial plants

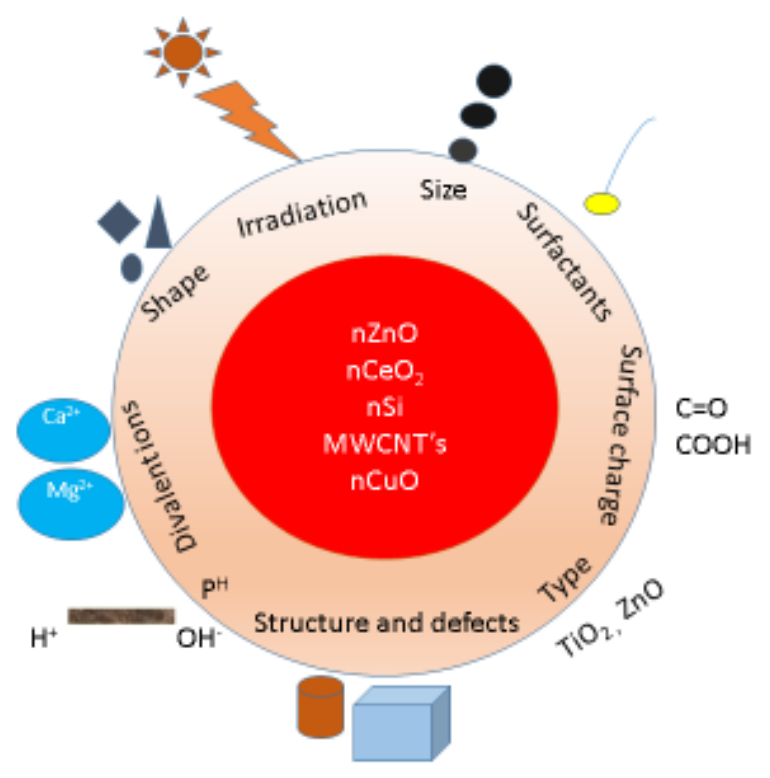




\section{Lessons learned: Are engineered nanomaterials toxic to terrestrial plants?}

P. Venkata Laxma Reddy ${ }^{\text {ac }}$, JA Hernandez-Viezcas ${ }^{\text {bcd }}$, J.R. Peralta-Videa ${ }^{\text {abc }}$, Jorge GardeaTorresdey ${ }^{\mathrm{abc} * *}$

${ }^{a}$ Environmental Science and Engineering PhD Program, The University of Texas at El Paso, 500 West Univ. Ave., El Paso, TX 79968, USA.

${ }^{b}$ Chemistry Department, The University of Texas at El Paso, 500 West Univ. Ave., El Paso, TX 79968, USA

'University of California Center for Environmental Implications of Nanotechnology (UC CEIN), The University of Texas at El Paso, 500 West Univ. Ave., El Paso, TX 79968, USA

*Corresponding author: jgardea@utep.edu (J. Gardea); P: 915-747-5359; F: 915-747-5748 


\begin{abstract}
The expansion of nanotechnology and its ubiquitous applications has fostered unavoidable interaction between engineered nanomaterials (ENMs) and plants. Recent research has shown ambiguous results with regard to the impact of ENMs on plants. On one hand, there are reports that show hazardous effects, while on the other hand, some reports highlight positive effects. This uncertainty whether the ENMs are primarily hazardous or whether they have a potential for propitious impact on plants, has raised questions in the scientific community. In this review, we tried to demystify this ambiguity by citing various exposure studies of different ENMs (nano-Ag, nano- $\mathrm{Au}$, nano-Si, nano- $\mathrm{CeO}_{2}$, nano- $\mathrm{TiO}_{2}$, nano- $\mathrm{CuO}$, nano- $\mathrm{ZnO}$, and $\mathrm{CNTs}$, among others) and their effects on various groups of plant families. After scrutinizing the most recent literature, it seems that the divergence in the research results may be possibly attributed to multiple factors such as ENM properties, plant species, soil dynamics, and soil microbial community. The analysis of the literature also suggests that there is a knowledge gap on the effects of ENMs towards changes in color, texture, shape, and nutritional aspects on ENM exposed plants.
\end{abstract}

Key words: Nanoparticle-plant interactions, Nanotoxicity, Fate, Transport, Transformation 


\section{Introduction}

Nanotechnology industry is progressing and it has rapidly emerged into a technological sensation in the last two decades. This industry is operating in numerous fields of science and is constantly expanding its applications (Barkalina et al., 2014; Ditta et al., 2015). Engineered nanomaterials (ENM) are the building blocks of nanotechnology. Their unique properties and new characteristics, compared to their bulk counterparts, are the reasons behind their industrial and scientific success. Although nanotechnology is already a billion dollar industry globally, extensive ongoing research proves that this technology is still in the exploration stage and it has been projected to grow further (Shapira \& Youtie, 2015). To meet the ever increasing industrial demand, NMs are manufactured expansively. This massive and unrestricted use of ENMs in recent years has led researchers to ponder the issues, questions, challenges, and consequences of their environmental impact (Gottschalk et al., 2015; Tolymat et al., 2015). Amongst the diverse studies that are been carried out, the impact of ENMs in ecosystems and their involvement in the food chain has conveyed some alarming discoveries. For the most part, experimental studies have proven that ENMs can pose undesirable effects to the food chain producers. There are some excellent reviews which have thoroughly emphasized these findings (Rico et al., 2011; GardeaTorresdey et al., 2014). The most compelling evidence is primarily attributed to the tendency of the plants to uptake ENMs through their roots, followed by translocation, biotransformation, and perturbation of physiological functions (Li et al., 2015). Impairment in physiological functions can affect seed germination, seedling growth, increase reactive oxygen species (ROS) generation, disrupt cell walls, and modify biomolecules such as: proteins, carbohydrates, lipids,

pigments, and hormones (Rico et al., 2014; Majumdar et al., 2014; Siddiqui et al., 2014). Conversely, reports show the positive effects of ENMs as they are proven to act as pesticides and 
fertilizers. There are some excellent reviews on the beneficial effects of ENMs on plant growth as well (Adhikari et al., 2010; Gopal et al., 2012; Tiwari et al., 2014). Overall, the impact of ENMs on plants is still debatable, and there is no conclusive explanation pertaining to this situation. In this review we explore various factors that have probably determined both the positive and negative responses (Figure 1). We include a brief discussion on two important facets of the ENMs-plant studies: The interactions of ENMs with environmental components (soil, water) prior to their interaction with plants and the corresponding responses as an outcome of ENMs exposure. Accordingly, it is expected that this review will be helpful to expand our knowledge about implications and impact of ENMs on terrestrial plants.

\section{Fate and transformations of ENMs' in environmental matrices and their impact}

Generally, upon disposal into the environment, the ENMs tend to interact with various environmental components and usually, undergo aggregation, dissolution, sedimentation, and transformation (Markus et al., 2015). The most recent estimates indicates that in 2010, between 8 to $28 \%$ of the ENMs released into the environment ended up in soils and 4 to $7 \%$ in water (Keller et al., 2013). Furthermore, several factors influence their levels of accumulation in various environmental compartments. According to Liu and Cohen (2014), accumulation of ENMs in sediments increases as their attachment to suspended solids in water increases. For instance, in a study carried out by Mueller and Nowack (2008), they reported that predicted environmental concentrations of $\mathrm{TiO}_{2} \mathrm{NPs}$ in water bodies around Switzerland was $0.7-16 \mu \mathrm{g} / \mathrm{L}$. These levels can vary geographically as they are in direct correlation with the degree of utilization of ENMs. In a similar study carried out on surface sediments of Xiamen Bay, China, it was reported that titania-based nanomaterial concentration was around $2.74 \mathrm{~g} / \mathrm{kg}$ (Luo et al., 
2011). It must also be noted that ENM concentrations at disposal sites such as wastewater treatment plants (WWTP) can vary in comparison to surface sediments. According to recent findings, the concentration of ENMs varies from 0.003 (fullerenes) to $21 \mathrm{ng} / \mathrm{L}\left(\mathrm{TiO}_{2} \mathrm{NPs}\right)$ for surface waters. However, the same ENMs at sewage treatment facilities were around $4 \mathrm{ng} / \mathrm{L}$ (fullerenes) to $4 \mu \mathrm{g} / \mathrm{L}\left(\mathrm{TiO}_{2} \mathrm{NPs}\right.$ ), respectively (Kunhikrishnan et al., 2015). In this context, wastewater treatment plants (WWTPs), as biosolid generators, are important intermediate conduit of ENMs from industry to arable land. Thus, there is a strong possibility for ENMs transformation prior to their interaction with plants. There are some critical reviews which have briefly discussed the stability, toxicity, fate, and transformation of ENMs in terrestrial ecosystems (Klaine et al., 2008 ; Peralta-Videa et al., 2011; Gardea-Torresdey et al., 2014; Keller et al., 2015).

\subsection{Physiochemical properties of ENMs}

Engineered nanomaterials are very diverse and offer extreme benefits in comparison to their bulk forms. Although there are beneficial advantages in the industry, nanostructured forms are also proven to be toxic in comparison to the bulk forms (Musante and White., 2012). The enhanced toxicity in comparison to the bulk is primarily attributed to the high surface area and ability to penetrate the tiny pores. In addition, the size also determines the fate and behavior of the ENMs. Bian et al. (2011) reported that the dissolution of ZnO NPs increase with the decrease in size of the NPs in the range of 15-240 nm diameter. The shape and morphology also affect the activity of ENMs. For example, the ionic strength strongly affected the aggregation of spherical ZnO NPs but had little or no impact on irregular ZnO NPs (Zhou et al., 2010). Ghosh et al. (2008) reported that humic acids, in combination with $\mathrm{pH}$, affected the colloidal behavior of aluminum oxide NPs. The surface charge of the NPs decreased as the $\mathrm{pH}$ increased. The surface 
charge can be a significant factor in the plant nanotoxicity studies. Zhu et al. (2012) concluded that small sized positively charged Au NPs were usually confined to the roots of terrestrial plants, whereas the negatively charged NPs were easily translocated to shoots and leaves. The fate of ENMs is also affected by surface coating (Buzea et al., 2007; Unrine et al., 2012). The nanomaterial stability can also be influenced by the light irradiation coupled with other chemical variables. The aggregation behavior of $\mathrm{C}_{60}$ NPs, before and after UV-A irradiation, was studied in solutions varying in ionic strength, ionic composition, and humic acids. Qu et al. (2010) reported that under UV illumination, the stability of $\mathrm{C}_{60}$ NPs increased, whereas their aggregation decreased in a medium containing $\mathrm{NaCl}$. The enhancement in stability was attributed to an increase in the negative surface charge and a reduction in the hydrophobicity of the NPs. Although it is clear that various physiochemical properties of ENMs have proven to determine their effects on plants, their optimization is yet to be known.

Chemicals present in the media can also trigger the transformation of ENMs. According to an experimental work, it was reported that Ag NPs have a tendency to combine with inorganic ligands, like sulfur, forming $\mathrm{Ag}_{2} \mathrm{~S}$ NPs. The sulfidation reduces the toxicity as the $\mathrm{Ag}_{2} \mathrm{~S}$ have lower solubility in environmental matrices. ZnO NPs also tend to combine with sulfur, forming $\mathrm{ZnS}$ (Ma et al., 2013). Although this transformation enhanced the stability, it is not clear if $\mathrm{ZnS}$ pose more or less toxicity than the reactant ZnO NPs. This study explains that inorganic ligands play a crucial role in the transformation as well as have the potential to influence the outcome of studies (Levard et al., 2012). As a matter of fact, inorganic ions have the potential to carry out redox reactions, triggering surface changes in ENMs. Liu et al. (2015) observed that $\mathrm{CeO}_{2} \mathrm{NPs}$ have the tendency to carry out a redox reaction with ferrous ions. This improved the colloidal stability by enhancing the zeta potential and hydrophilicity of $\mathrm{CeO}_{2}$ NPs. The increase in 
hydrophilicity of ENMs could have a potential impact on their transport. The presence of heavy metals/metalloids such as lead and arsenic in soil, and their impact on ENMs, is still unknown. There are potential knowledge gaps about how metal pollution in soil can affect the ENMs fate.

On the other hand, other factors like cationic valence also affect the behavior of ENMs. For example, monovalent and divalent cations enhance the aggregation of $\mathrm{TiO}_{2} \mathrm{NPs}$ in soil and water, but higher aggregation is produced by divalent species (French et al., 2009). Extra polymeric substances (EPS) derived from phytoplankton affected the stability of Cu-based NPs. The EPS also have a significant impact on the dissolution of ENMs in the presence of other chemical variables like ionic strength and $\mathrm{pH}$. Recent studies have suggested the potent role of EPS in the speciation of Cu-based NPs, which results in formation of additional free $\mathrm{Cu}^{2+}$ ions, producing other forms of $\mathrm{Cu}$ toxicity (Adeleye et al., 2014). The environmental media also play an important role in the toxicity of ENMs. For instance, photochemical reactions can modify the transformation of CNTs in aqueous media. Moreover, under UV irradiation in the same medium, MWCNTs had the highest ROS production, compared to $\mathrm{C}_{60}$ and SWCNTs (Chae et al., 2011). Since the UV irradiation is proven to affect the toxicity of ENMs, it would be interesting to find out the impact of natural weather conditions such as temperature, humidity, and precipitation. The composition of media also influences the surface chemistry, causing unexpected behavior of ENMs (Ottofuelling et al., 2011). Keller et al. (2010) studied the behavior of $\mathrm{TiO}_{2}$, $\mathrm{ZnO}$, and $\mathrm{CeO}_{2} \mathrm{NPs}$ in water from a lagoon, a river, ground water, and sea water. These researchers found that the electrophoretic mobility of the three ENMs was highly influenced by the organic matter content and ionic strength but no by the $\mathrm{pH}$. However, it is not clear whether similar behavior will be exhibited by carbon-based ENMs such as CNTs. 
A key point to be noted is the possible change to occur in ENMs during the extended stay (aging) in environmental matrices. Reports indicates that $\mathrm{AgO}$ and $\mathrm{ZnO}$ NPs have the tendency to undergo alterations during the aging process in different suspensions. In one of these studies, the influence of aging on the speciation and chemical stability of $\mathrm{Ag}$ and $\mathrm{ZnO}$ NPs in kaolin suspensions was examined for 18 months. According to the study, Ag NPs remained unchanged in sodium nitrate suspensions; however, silver chloride was identified with the metallic Ag NPs in sodium chloride suspensions. On the other hand, $\mathrm{ZnO}$ NPs were rapidly converted via destabilization/dissolution mechanisms to $\mathrm{Zn}^{2+}$ inner-sphere sorption complexes within one day of reaction, remaining in the same form for almost 12 months (Scheckel et al., 2010). However, various other factors may have the potential to influence the outcome. For instance, impurities and additives used in the nanomaterial synthesis can be released when ENMs interact with environmental matrices. Liu et al. (2013) carried out a study to examine the phosphorous released from impurities in the synthesis of five different $\mathrm{TiO}_{2} \mathrm{NPs}$. Authors reported that $50 \mathrm{~nm}$ anatase $\mathrm{TiO}_{2}$ had higher phosphorous, which seemed to peak at $\mathrm{pH}$ of 11.2. Likewise, silicon, which had a similar role as mentioned above, was found to be released into aqueous media attached to $\mathrm{TiO}_{2}$ NPs during the synthesis process (Liu et al., 2014). As phosphorous is believed to be essential nutrient for plant growth, the consequences of the elevated phosphorous levels in soil can lead to undesirable effects. Nonetheless, the existence of phosphorous is believed to affect the structural and morphological aspects of some other nanomaterials. Rathnayake et al. (2014) reported that ZnO NPs have the tendency to interact with phosphate in the media and transform into two structurally and morphologically heterogeneous products. The two products formed were crystalline zinc phosphate phase (hopetite) and nanoscale zinc, which contains the core $\mathrm{ZnO}$ with a shell of $\mathrm{Zn}_{3}\left(\mathrm{PO}_{4}\right)_{2}$. The role of solubility of available phosphorous also seemed 
to play a part. In an experimental work, the impact of insoluble phosphorous on $\mathrm{ZnO}$ was studied by using hydroxyapatite (HAP) mineral. It was observed that under acidic conditions, $80 \% \mathrm{ZnO}$ was transformed into scholzite in a span of 4 hours. In contrast, under neutral or alkaline conditions, the adsorption of $\mathrm{Zn}^{2+}$ on HAP was observed and, eventually, resulted into a structural transformation of over $60 \% \mathrm{ZnO}$ NPs to amorphous inner-sphere $\mathrm{Zn}$ adsorption complexes in a span of 30 days ( Lv et al., 2014). In summary, it must be observed that same $\mathrm{ZnO}$ NPs transformed into different structural forms, based on the type of phosphorous form and $\mathrm{pH}$ conditions. Thus, it can be summarized that various factors can influence the degree of toxic impact of ENMs (Figure 2). The impact of different ENM synthesis methods as well as their post modification on the stability and potential phytotoxicity towards plants is yet to be studied on a broader scale.

\subsection{Soil properties and their role in the effects of ENMs in plants}

Soils are one of the major disposal sinks for ENMs. Thus, it is expected that terrestrial plants will be in contact with ENMs deposited in places reached by plant roots. Currently, our knowledge about the interactions of ENMs with soil is very limited. Once ENMs reach the soil, they will be either physically or chemically adsorbed onto the surface of the soil particles. They may also undergo chemical transformations triggered by soil organic matter. ENMs can enter the pores of large sized soil particles remaining suspended for longer periods (Jaisi and Elimilech, 2009). The mobility and retention dynamics of ENMs in the soil determine their overall uptake and bioavailability. Column experiments with loamy sand soil have shown that the retention of $\mathrm{Ag}$ NPs was higher in the presence of soil cations such as $\mathrm{K}^{+}$and $\mathrm{Ca}^{+}$. The authors concluded that the retention was due to a decrease in ionic strength and the release of more clay into soil (Liang et al., 2013). The soil texture also affects the mobility of ENMs. In a 
work carried out by Zhang et al. (2012), it was observed that fullerene NPs exhibited different transport behavior in two different media, i.e Ottawa sand (quartz) and Lula soil (containing a mixture of soil organic components and quartz). The size of the nanomaterials has also proven to impact their retention in the porous media. Column experiments with silicon NPs of 8 and $52 \mathrm{~nm}$ demonstrated that larger NPs $(52 \mathrm{~nm})$ had lower retention (Wang et al., 2012). The coating of the ENMs also has an impact on the transport in the soil media. In a work carried out by Zhao et al. (2012), the transport distances ( $\mathrm{cm}$ ) for bare $\mathrm{ZnO}$ NPs and coated $\mathrm{ZnO}$ was studied in both sandy and sandy loam soils. It was observed that the distances travelled by bare $\mathrm{ZnO}$ in either soils were 19.2 and $5.3 \mathrm{~cm}$, while distances for coated NPs were 21.4 and $6.9 \mathrm{~cm}$, respectively. It could be inferred from this study that the surface coating of $\mathrm{ZnO}$ reduced its deposition rates in soil. Lastly, the pore water velocity in the porous media was also proven to significantly influence the transport of the nanomaterials. In a one dimensional flow through column experiment carried out by Liu et al. (2009), it was reported that the transport and mobility of MWCNTs was greater at a pore water velocity greater than 4.0 millidarcy $(\mathrm{m} / \mathrm{d})$. The above literature clearly shows the need for more research in this direction. As it could be inferred, the soil habitat has a huge impact on the ENMs fate and uptake. Soil associated factors such as texture, $\mathrm{pH}$, and organic matter content are factors to be included in ENM-based studies.

In order to better understand the interaction of soil-landed ENMs with plants, it is necessary to understand their fate, mobility, and transformations in soil. Firstly, the aging of nanomaterials in the soil can have a dramatic impact on their toxic potential. Mc Shane et al. (2014) reported that the potential toxic activity of various ENMs changes with their residence (aging) in soil. These authors compared the $\mathrm{Cu}^{2+}$ activity from $\mathrm{CuO}$ (nano), $\mathrm{CuO}$ (micro), and $\mathrm{Cu}\left(\mathrm{NO}_{3}\right)_{2}$ for 56 days. They found that nano $\mathrm{CuO}$ had higher $\mathrm{Cu}^{2+}$ release than micro $\mathrm{CuO}$ but lower than the salt form. 
In addition, the $\mathrm{Cu}^{2+}$ activity was very high in the initial 11 days. On the other hand, the silverbased ENMs exhibited a different behavior during the aging process in the soil. It was reported that Ag NPs have strong sorption with soil ligands in the first few hours. As time passed, the Ag ion release increased by more than 10 times (Benoit et al., 2013). These results suggest the need for further studies on all the types of ENMs, as it seems that the aging triggers varied responses. As previously mentioned, the colloidal stability of ENMs is affected by the $\mathrm{pH}$ and humic acids present in the soil. Humic acids induce the aggregation of ENMs in the soil (Mashayeki et al., 2012). The reviews by Grillo et al. (2015) and Pachapur et al. (2015) have provided crucial information pertaining to the interactions between ENMs and organic matter in various environmental media. The reviews suggest that ENMs such as $\mathrm{TiO}_{2}$ have higher mobility in the mineral soil in comparison to soil rich in organic colloids.

\subsection{Sorption behavior of ENMs}

The chemical nature of ENMs allows different types of bondings with soil components such as hydrophobic interactions, hydrogen bonding, and electrostatic interactions, along with others. In addition, ENMs tend to either adsorb or absorb the chemicals present in the soil matrix, which may modify their effects on plants. The research in recent years have proven that a wide range of toxic chemicals such as radioactive metals, pesticides, polychlorinated biphenyl (PCBs), and heavy metals have the tendency to undergo sorption on the ENMs surface. A work carried out by Feng et al. (2012) showed that nano $\mathrm{CeO}_{2}$ exhibits a strong adsorption tendency towards extremely toxic elements such as arsenic. $\mathrm{TiO}_{2}$ NPs have also shown adsorption tendency towards radioactive elements. In a study carried out by Tan et al. (2007), it was proven that the $\mathrm{pH}$, in combination with humic and fulvic acids, altered the sorption of thorium and $\mathrm{TiO}_{2}$. The sorption process has shown to modulate the transport of contaminants. An experiment performed 
in two sandy soil columns showed that at a low concentration (1.55 to $12.8 \mathrm{mg} / \mathrm{L}), \mathrm{C}_{60}$ increased the mobility of PCBs and phenanthrene (Zhang et al., 2011).

Recent studies have shown that almost all the well-known carbon-based nanomaterials have sorption tendency for carcinogenic pesticides such as lindane and atrazine. The SWCNTs can bind dimethyl phthalate and diethyl phthalate. However, this sorption is reduced by humic acids due to the competition effect (Wang et al., 2010). It is believed that the sorption of nano metal oxides is higher than bulk metal oxides due to the higher surface area. This was proven in one experimental study, where pyrene was more absorbed onto the nanoscale zinc, aluminum, and titania oxides, in comparison to their bulk counter parts (Wang et al., 2008). Recent studies have shown that personal care products and pharmaceuticals such as ketoprofen, carbamazepine, and bisphenol A can be bound to carbon-based ENMs such as MWCNTs and graphene (Liu et al., 2014). Although there is no concrete evidence on how personal care products will affect terrestrial plants if they are taken up along with ENMs, it is speculated that they can pose a risk. On the other hand, there is experimental evidence that the sorption properties of carbon-based ENMs decrease in the presence of oxygen and irradiation (Shen et al., 2014). In fact, the European Commission and the EPA (Petrie et al., 2015) have created a list of emerging contaminants that could potentially interact with the sorption properties of ENMs, changing their impact on plant toxicity.

\subsection{Soil microbial community}

Soil is a vital habitat for large number of organisms, including plants, nematodes and microbes that are essential in nutrient cycling, matter decomposition, and nitrogen fixation. Any disturbances to these organisms can potentially have huge implications in ecosystems. Studies have shown that ENMs can cause serious perturbations to soil microbiota. Rodrigues et al. 
(2012) reported that bacteria eventually recovered from adverse effects of SWCNTs, whereas the fungal microbiota showed no signs of recovery. Another study showed that NPs of FeO and Ag decreased fungal biomass in clover arbuscular micorrhizal fungi (Feng et al., 2013). This study highlights the implications of decreased nitrogen fixation in terrestrial plants and the potential deterioration of soil fertility.

Paradoxically, ENMs may not have a similar inhibitory effect on the pathogenic fungi. For instance, Rispail et al. (2014) reported that quantum dots and super paramagnetic nanoparticles have proven to exhibit little or no toxic effects on Fusarium oxysporum. Amongst the various bacteria that persist in the soil, it must be noted that nitrifying bacteria are more susceptible to ENMs toxicity than nitrogen fixing and denitrifying bacteria. Different types of coated quantum dots were exposed to soil bacterial and affected their gene expression pertaining to the nitrogen cycling (Yang et al., 2012). There are also reports that suggest that ENMs affect ammonia oxidizing bacteria. Luo et al. (2015) reported that $\mathrm{TiO}_{2} \mathrm{NPs}$ have significant inhibitory effects on ammonia oxidizing bacteria, while $\mathrm{CeO}_{2}$ NPs showed to affect soil denitrifying bacteria. Likewise, ZnO NPs showed toxicity to the amylolytic activity, denitrification, and urea degradation in Bacillus subtilis and Pseudomonas aeruginosa (Santimano and Kowshik, 2013). Our knowledge about the impact of these ENMs in methanogenic and sulphur oxidizing bacteria is still limited. In addition to the microbial biota, other life forms such as nematodes are shown to be affected by ENMs. Hu et al. (2010) reported that $\mathrm{ZnO}$ exhibited higher toxicity on the nematode Eisenia fetida than $\mathrm{TiO}_{2}$.

Conversely, chemicals extracellularly released by soil microbes can influence the stability and toxicity of ENMs persisting in the soil. Metz et al. (2009) reported that lignolytic fungus-based extracellularly released compound has proven to facilitate the hydroquinone driven Fenton's 
reaction on NPs, having huge impact on the transformation of CdSe core/ZnS shell quantum dots (QD) functionalized with poly(ethylene glycol). The QD was transformed to Se aggregates. This study has proven that the biologically-driven natural redox conditions can have an impact on the fate and transformation of ENMs in soil.

\section{Impact of ENMs exposure to terrestrial plants}

Several studies have shown that ENMs affect terrestrial plants in different ways. Disturbances in physiological aspects such as seed germination, stunted growth, yield, crop quality, and biochemical aspects like abiotic stress, lipid peroxidation, and cell wall disruption have been extensively reported (Table 1).

\subsection{Growth and development}

The impact of the ENMs on plant growth and development is being extensively studied. The survey of the recent literature indicates that the impacts of ENMs in plants have been assessed at germination and seedling growth, and during the entire life cycle. Studies at germination stage and seedling growth seem to begin in the middle 2000's with a study on soybean germination (Lin and Xing, 2007). After that, several studies have explored the effects of various ENMs in different plant species. Lin and Xin (2007) studied the effects of MWCNTs aluminum, alumina, zinc, and zinc oxide NPs at 20,200, and $2000 \mathrm{mg} / \mathrm{L}$ on six plant species (radish, rape, ryegrass, lettuce, corn, and cucumber). Authors concluded that ENMs had little impact on seed germination, except for Zn NPs that at $2000 \mathrm{mg} / \mathrm{L}$ had an inhibition effect on ryegrass, whereas the ZnO NPs had a similar effect on corn. The inhibition of root length was observed for either Zn-based ENMs at concentrations such as $2000 \mathrm{mg} / \mathrm{L}$. However, concentrations higher than 500 
$\mathrm{mg} / \mathrm{L}$ would be rare in environments away from ENM factories or where these ENMs are not intentionally used.

On the other hand, exposure of $\mathrm{TiO}_{2}$ NPs to mungbean (Vigna radiata) seeds in Murashigi and Skoog (MS) medium at concentrations from $250-2500 \mathrm{mg} / \mathrm{L}$ did not yield any abnormal result (Theerakarunwong \& Chouychai, 2013). In contrast, the same $\mathrm{TiO}_{2} \mathrm{NPs}$ at concentrations ranging from 0.2 to $4.0 \%$ delayed germination progression for the first $24 \mathrm{~h}$ in Zea mays L. and Vicia narbonensis L. (Castigilone et al., 2011). Likewise, $\mathrm{TiO}_{2}$ NPs at 0, 5, 20, 40, 60 and $80 \mathrm{mg} / \mathrm{L}$, along with the bulk counterpart, were tested on fennel seed germination and early growth. It was reported that after 14 days of seed incubation, the overall germination percentage increased with exposure to $60 \mathrm{mg} / \mathrm{L}$ (Feizi et al., 2012). Twelve nm $\mathrm{SiO}_{2} \mathrm{NPs}_{\text {at }}$ $8 \mathrm{~g} / \mathrm{L}$ also increased tomato seed germination in terms of mean germination time, seed germination index, seed vigor index, seedling fresh and weights (Siddiqui and Waihibi, 2014). Reports also show that CNTs increase rice seed germination (Nair et al., 2012). Likewise, MWCNTs improve the growth of tobacco seedlings (Khodakovskaya et al., 2012). CNTs at a concentration of $(10-40 \mu \mathrm{g} / \mathrm{mL})$ were found to penetrate tomato seeds and affect their germination and growth rates (Khodakovskaya et al., 2013). These results emphasize the impact of concentration and provide evidence that different plants react in different ways to a specific nano exposure. Another important aspect is that ENM exposure to seeds may yield misleading conclusions. For example, graphene at low concentration showed mixed results on tomato seed germination and seedling growth. On one hand, it increased seed germination, but on the other hand, reduced plant biomass with taller seedlings (Zhang et al., 2015).

The transformation of ENMs in the plants is also an important aspect. In the majority of cases, the transformed products could be more potentially toxic or beneficial for plant growth and 
development. In a study carried out by Hernandez-Viezcas et al. (2013), soybean seeds were germinated and cultured in organic soil in the presence of $\mathrm{ZnO}$ and $\mathrm{CeO}_{2} \mathrm{NPs}$ at a concentration of $500 \mathrm{mg} / \mathrm{kg}$ and $1000 \mathrm{mg} / \mathrm{kg}$, respectively. As per the study, both $\mathrm{ZnO}$ and $\mathrm{CeO}_{2}$ NPs were taken up and biotransformed, to a certain extent, within the plant. The micro-X-ray absorption near edge structure ( $\mu$-XANES) showed that the $\mathrm{ZnO}$ form was completely absent inside of the plant. Instead, the observed form was $\mathrm{Zn}-\mathrm{O}$ resembling the $\mathrm{Zn}$ - citrate. On the other hand, most of the cerium content existed in the form of $\mathrm{CeO}_{2}$; however, a small portion of oxidized form of cerium(IV) was also observed. There are also some experimental evidences showing that ENMs, in addition to changing their chemical form, change their shapes during the transformation inside the plant. In a study carried out by Ma et al. (2011), lanthanum oxide $\left(\mathrm{La}_{2} \mathrm{O}_{3}\right)$ NPs were exposed to cucumber plants at specific conditions explained in the study. TEM coupled to EDS, STXM, and NEXAFS were used to assess the results. As per authors observations, $\mathrm{La}_{2} \mathrm{O}_{3} \mathrm{NPs}$ and $\mathrm{LaCl}_{3}$ were both transformed to needle-like $\mathrm{LaPO}_{4}$ nanoclusters in the intercellular regions of the cucumber roots. $\mathrm{TiO}_{2}$ NPs have also proven to affect plant growth in a positive way. An experiment carried out on wheat with bulk and $\mathrm{TiO}_{2} \mathrm{NPs}$ at five different concentrations showed that $\mathrm{TiO}_{2} \mathrm{NPs}$ at concentrations of 2 and $10 \mathrm{ppm}$, respectively, enhanced the seedlings and shoot length, in comparison to the bulk $\mathrm{TiO}_{2}$ (Feizi et al., 2012). Similarly, the exposure of tomato plants to $\mathrm{CeO}_{2}$-NPs $(0.1-10 \mathrm{mg} / \mathrm{L})$ seemed to exhibit inconsequential or slightly positive effects on plant growth and tomato production (Wang et al., 2012).

There are also some research findings showing that at certain concentrations and conditions, ENMs have beneficial impacts on plant growth. Water soluble carbon nanotubes (wsCNTs) were experimentally proven to improve the growth of common gram (Cicer arietinum). At 6.0 $\mu \mathrm{g} / \mathrm{mL}$, the wsCNTs had a positive effect on every part of the plant. According to the authors, the 
positive effects were primarily attributed to the better water absorption and retention by the plant (Tripathi et al., 2011). Furthermore, in a typical study carried out by Tripathi and Sarkar (2015), water soluble carbon nano-dots (wsCND) upon exposure to wheat plants under dark and light conditions proved to enhance the growth of roots and shoots.

\subsection{Reactive oxygen species (ROS) production and other biochemical perturbations}

In general, reactive oxygen species (ROS) production is part of the normal plant biochemical processes (Suzuki et al., 2012). Generally, ROS include free radicals such as superoxide anion $(\mathrm{O} 2 \bullet-)$, hydroxyl radical $\left({ }^{\circ} \mathrm{OH}\right)$, as well as non radical molecules like hydrogen peroxide $\left(\mathrm{H}_{2} \mathrm{O}_{2}\right)$, and singlet oxygen $\left({ }^{1} \mathrm{O}_{2}\right)$ (Gill and Tuteja, 2010). Generally, in normal plants, ROS are formed by the inevitable leakage of electrons onto $\mathrm{O}_{2}$ from the electron transport activities of chloroplasts, mitochondria, and plasma membranes; or as a byproduct of various metabolic pathways localized in different cellular compartments. In a healthy plant, ROS act as signaling molecules (Thannikal and Fannburg, 2000). In other instances such as abiotic and biotic stresses, there is an excessive production of ROS. In the case of elevated ROS levels, the plant has innate scavenging mechanisms for the depletion of ROS. These mechanisms can be enzyme-based and include superoxide dismutase (SOD), guaiacol peroxidase (GPX), ascorbate peroxidase (APX), and catalase (CAT) (Mazhoaudi et al., 1997); or non-enzyme-based anti-oxidants including ascorbate (AsA), glutathione (GSH), carotenoids, tocopherols, and phenolics. In the absence or ineffectiveness of the scavengers, the excess ROS could lead to various effects such as protein oxidation, DNA damage, lipid peroxidation, electrolyte leakage, and membrane damage, among others. The overall process will eventually trigger oxidative damage and ultimately cell death (Sharma et al., 2012). There are several works reporting that ENMs have a 
tendency to induce ROS generation (Hong et al., 2005; Navarro et al., 2008; Lee et al., 2010; Rico et al. 2015). Other reports show results pertaining to genetic, hormonal, and other biomolecule disruptions (Atha et al., 2012; Zhao and Liu, 2012). It has yet to be proven whether these biomolecule perturbations are only consequence of excess ROS or if there are other ways that ENMs directly affect the biomolecules. Furthermore, researchers must be sure that factors such as light, water, and temperature, which also contribute to ROS generation and affect biomolecular functions, are not having any impact on the experimental studies.

In a work reported by Faisal et al. (2013), nickel oxide nanoparticles (NiO NPs) were exposed to tomato seedlings in the concentration range of $0.025-2.0 \mathrm{mg} / \mathrm{mL}$. In comparison to control, it was reported that oxidative stress, indicated by elevated activity of catalase (CAT), glutathione (GSH), and superoxide dismutase (SOD), was produced. Authors concluded that the dissolution of $\mathrm{Ni}$ ions from NiO NPs triggered a mitochondrial-dependent intrinsic apoptotic pathway, leading to cell death. In another work, $\mathrm{CeO}_{2} \mathrm{NPs}$ exposed to cilantro (Coriandrum sativum) at $125 \mathrm{mg} / \mathrm{kg}$ increased CAT contents in the shoots, whereas the level of ascorbate peroxidase was higher in the roots (Morales et al., 2013). In another study, Arabidopsis and rice leaf protoplasts were exposed to SWCNTs at $25 \mu \mathrm{g} / \mathrm{mL}$, resulting in cell death. Exposure to SWCNT caused adverse cellular responses, including oxidative stress, cell aggregation, chromatin condensation, and $\mathrm{H}_{2} \mathrm{O}_{2}$ accumulation, eventually leading to cell death (Shen et al., 2010).

In depth analyses of various other cellular components such as DNA, proteins, lipids, and membranes have also been indicators of phytotoxicity due to ENMs' exposure. This has been primarily attributed to ROS formation upon exposure to ENMs. The genotoxic effects of $\mathrm{ZnO}$ and $\mathrm{CuONPs}$ was studied on buckwheat (Fagopyrum esculentum). Random amplified polymorphic DNA assays showed different DNA polymorphisms at 2,000 and 4,000 $\mathrm{mg} / \mathrm{L}$ of 
$\mathrm{ZnO}$ and $\mathrm{CuO}$ NPs, compared to controls (Lee et al., 2013). In a similar work, ZnO NPs were exposed onto garlic (Allium sativum L.) and it was observed that mitotic index decreased in a concentration- and time-dependent manner. Other effects of ZnO NPs on garlic plants included mitotic aberrations, mainly consisting in chromosome stickiness, bridges, breakages, and laggings. It was observed that the overall percentage of abnormal cells proportionally increased as the $\mathrm{ZnO}$ concentration increased. The investigation provided new information for the possible genotoxic effects of ZnO NPs on plants (Shaymurat et al., 2009). In another genetic toxicity studies, Alium cepa roots were exposed to bismuth oxide NPs at $12.5,25,50,75$, and $100 \mathrm{mg} / \mathrm{L}$ for four hours. Results showed that at specific concentrations discussed in the work, there were various harmful effects such as increased mitotic index and total chromosomal aberrations (Liman, 2013). The oxidative stress on exposure to ENMs eventually has effects on the protein content. According to Vannini et al. (2014), exposure of Triticum aestivum L. seedlings to $10 \mathrm{mg} / \mathrm{L}$ of AgNPs resulted in the alteration of various proteins that are extensively involved in cell metabolism. Another work performed with Oryza sativa L. showed that twenty-eight responsive proteins were identified. The affected proteins were involved in various vital biochemical process such as oxidative stress tolerance, transcription and protein degradation, cell wall and DNA/RNA/protein direct damage, $\mathrm{Ca}^{2+}$ regulation, and signaling, cell division, and apoptosis, among others (Mirjazani et al., 2014). In order to enhance our understanding, advanced molecular approaches such as proteomics and genomics must be extensively implemented. According to Majumdar et al. (2015), proteomic analysis of kidney bean seeds from plants exposed to $\mathrm{CeO}_{2} \mathrm{NPs}$ has resulted in downregulation of essential proteins associated with nutrient storage and carbohydrate metabolism. It would be interesting to know if other ENMs affect the same or other proteins in beans. 
In addition to having an effect on important biomolecules such as proteins, nucleic acids and other molecules, the exposure of MWCNT to Allium cepa has revealed that the uptake in root cells affects cellular morphology, membrane integrity, and mitochondrial functions ( Ghosh et al., 2015). Furthermore, Nair and Chung (2015) carried out a study where AgNPs were exposed to mung bean (Vigna radiate) in half strength MS agar medium, at $0,5,10,20$, and $50 \mathrm{mg} / \mathrm{L}$ for 21 days. The experimental results, showed that at higher concentration of AgNPs, the total chlorophyll was reduced, whereas the hydrogen peroxide and lipid peroxidation levels were increased.

\subsection{Nutritional quality}

In addition to various effects on defense and growth aspects, ENMs are also proven to affect the nutritional quality of food crops. Rico et al. (2013) reported that rice grains from $\mathrm{CeO}_{2} \mathrm{NP}-$ treated plants exhibited less Fe, S, glutelin, lauric and valeric acids, and starch, in comparison to bulk $\mathrm{CeO}_{2}$ treated plants. Rico et al. (2014) also reported that at $125 \mathrm{mg} / \mathrm{kg}, \mathrm{CeO}_{2} \mathrm{NPs}$ altered the amino acid content, especially for the linoleic acid composition of wheat. Experimental results with $\mathrm{ZnO} \mathrm{NPs}$ showed increased starch content at $400 \mathrm{mg} / \mathrm{kg}$. Whereas, $\mathrm{CeO}_{2} \mathrm{NPs}_{\text {at }}$ similar concentration affected sucrose content. According to the study, it must also be noted that, although $\mathrm{ZnO}$ NPs did not impact protein fractionation, there was a case where $\mathrm{CeO}_{2} \mathrm{NPs}_{\text {at }}$ $400 \mathrm{mg} / \mathrm{kg}$ increased globulin and decreased glutelin as well as phenolic content ( Zhao et al., 2014). Thus, the carbohydrate and protein value was affected. Likewise, other experimental studies have proven that $\mathrm{CeO}_{2}$ NPs have potential to alter the carbohydrate levels in cilantro plants (Morales et al., 2013. The impact of ENMs on other nutritional aspects such as vitamins, fiber, taste, and texture of food crops must be carefully scrutinized.

\section{Conclusions}


Engineered nanomaterials are a vital part of the emerging nanotechnology industry. As of now, the research about the impact of ENMs on terrestrial plants is still an ongoing process and it demands further research. Based on the current knowledge, it could be concluded that ENMs' impacts on terrestrial plants depend on multiple factors. However, most often, but not always, concentrations less than $100 \mathrm{ppm}$, especially $10-40 \mathrm{mg} / \mathrm{kg}$, have proven to exhibit beneficial effects on plant growth, whereas higher concentrations, at higher ranges, have inhibitory effects. $\mathrm{TiO}_{2}$ and $\mathrm{Si}$-based ENMs are either beneficial or have less negative impact on the plants. There are still a lot of knowledge gaps in our understanding of the impacts of ENMs in plants. Considering the potential benefits as well as threat posed by ENMs towards terrestrial plants, more in depth research must be carried out on the plant cell aspects such as membrane disruptions, cell wall lysis, susceptibility to biotic pathogens, signal transduction, gene expression, hormone release, and ROS production, among others. Furthermore, there is a need for studies about the impact of ENMs on color, texture, taste, and nutritional aspects of plants that are major components in the food chain.

\section{Acknowledgements}

This material is based upon work supported by the National Science Foundation and the Environmental Protection Agency under Cooperative Agreement Number DBI-1266377. Any opinions, findings, and conclusions or recommendations expressed in this material are those of the author(s) and do not necessarily reflect the views of the National Science Foundation or the Environmental Protection Agency. This work has not been subjected to EPA review and no official endorsement should be inferred. The authors also acknowledge the USDA grant number 2011-38422-30835 and the NSF Grants \# CHE-0840525 and DBI-1429708. Partial funding was provided by the NSF ERC on Nanotechnology-Enabled Water Treatment (EEC-1449500). This 
work was also supported by Grant 2G12MD007592 from the National Institutes on Minority Health and Health Disparities (NIMHD), a component of the National Institutes of Health (NIH).

J. L. Gardea-Torresdey acknowledges the Dudley family for the Endowed Research Professorship, the Academy of Applied Science/US Army Research Office, Research and Engineering Apprenticeship program (REAP) at UTEP, grant \# W11NF-10-2-0076, sub-grant 13-7, and STARs programs of the University of Texas System.

\section{References}

Adeleye, A. S., Conway, J. R., Perez, T., Rutten, P., Keller, A., 2014. Influence of extracellular polymeric substances on the long-Term fate, dissolution, and speciation of copper-based nanoparticles. Environ. Sci. Technol. 48, 12561-12568.

Adhikari, T., Biswas, A. K., Kundu, S., 2010. Nano-fertiliser-a new dimension in agriculture. Indian J. Fert. 6, 22-24.

Adhikari, T., Kundu, S., Biswas, A. K., Tarafdar, J. C., Subba Rao, A., 2015. Characterization of zinc oxide nano particles and their effect on growth of maize (Zea mays L.). Plant. J. Plant Nutr. 38, 1505-1515.

Atha, D. H., Wang, H., Petersen, E. J., Cleveland, D., Holbrook, R. D., Jaruga, P., et al., 2012. Copper oxide nanoparticle mediated DNA damage in terrestrial plant models. Environ. Sci. Technol. 46, 1819-1827.

Barkalina, N., Charalambous, C., Jones, C., Coward, K., 2014. Nanotechnology in reproductive medicine: emerging applications of nanomaterials. Nanomedicine. 10, 921-938. 
Basiuk, E. V., Ochoa-Olmos, O. E., De la Mora-Estrada, L. F., 2011. Ecotoxicological effects of carbon nanomaterials on algae, fungi and plants. J. Nanosci. Nanotechnol. 11, 3016-3038.

Begum, P., Fugetsu, B., 2012. Phytotoxicity of multi-walled carbon nanotubes on red spinach (Amaranthus tricolor L) and the role of ascorbic acid as an antioxidant. J. Hazard. Mater. 243, 212-222.

Benoit, R., Wilkinson, K. J., Sauvé, S., 2013. Partitioning of silver and chemical speciation of free Ag in soils amended with nanoparticles. Chem. Cent. J. 7, 75.

Bian, S. W., Mudunkotuwa, I. A., Rupasinghe, T., \& Grassian, V. H., 2011. Aggregation and dissolution of $4 \mathrm{~nm} \mathrm{ZnO}$ nanoparticles in aqueous environments: influence of $\mathrm{pH}$, ionic strength, size, and adsorption of humic acid. Langmuir. 27, 6059-6068.

Boonyanitipong, P., Kositsup, B., Kumar, P., Baruah, S., Dutta, J., 2011. Toxicity of ZnO and $\mathrm{TiO}_{2}$ nanoparticles on germinating rice seed oryza sativa. Int. J. Biosci. Biochem Bioinforma. 1, 282.

Bouchard, D., Zhang, W., Powell, T., Rattanaudompol, U. S., 2012. Aggregation kinetics and transport of single-walled carbon nanotubes at low surfactant concentrations. Environ. Sci. Technol. 46, 4458-4465.

Bouwmeester, H., Brandhoff, P., Marvin, H. J., Weigel, S., Peters, R. J., 2014. State of the safety assessment and current use of nanomaterials in food and food production. Trends Food Sci. Technol. 40, 200-210.

Buzea, C., Pacheco, I. I., Robbie, K., 2007. Nanomaterials and nanoparticles: sources and toxicity. Biointerphases. 2, MR17-MR71. 
Castiglione, M. R., Giorgetti, L., Geri, C., Cremonini, R., 2011. The effects of nano-TiO 2 on seed germination, development and mitosis of root tip cells of Vicia narbonensis L. and Zea mays . J. Nanopart. Res. 13, 2443-2449.

Chae, S. R., Watanabe, Y., Wiesner, M. R., 2011. Comparative photochemical reactivity of spherical and tubular fullerene nanoparticles in water under ultraviolet (UV) irradiation. Water Res. 45, 308-314.

Chakravarty, D., Erande, M. B., Late, D. J., 2015. Graphene quantum dots as enhanced plant growth regulators: effects on coriander and garlic plants. J. Sci. Food Agr. 13, 27722778.

Chen, R., Ratnikova, T. A., Stone, M. B., Lin, S., Lard, M., Huang, G., et al., 2010. Differential uptake of carbon nanoparticles by plant and mammalian cells. Small. 6, 612-617.

Dahle, J. T., Arai, Y., 2014. Effects of Ce (III) and $\mathrm{CeO}_{2}$ nanoparticles on soil-denitrification kinetics. Arch. Environ. Contam. Toxicol. 67, 474-482.

Dehkourdi, E. H., Mosavi, M., 2013. Effect of anatase nanoparticles $\left(\mathrm{TiO}_{2}\right)$ on parsley seed germination (Petroselinum crispum) in vitro. Biol. Trace. Elem. Res. 155, 283-286.

Dimkpa, C. O., McLean, J. E., Martineau, N., Britt, D. W., Haverkamp, R., Anderson, A. J., 2013. Silver nanoparticles disrupt wheat (Triticum aestivum L.) growth in a sand matrix. Environ. Sci. Technol. 47, 1082-1090.

Ditta, A., Arshad, M., Ibrahim, M., 2015. Nanoparticles in Sustainable Agricultural Crop Production: Applications and Perspectives. In Nanotechnology and Plant Sciences, 55-75. 
Faisal, M., Saquib, Q., Alatar, A. A., Al-Khedhairy, A. A., Hegazy, A. K., Musarrat, J., 2013. Phytotoxic hazards of NiO-nanoparticles in tomato: a study on mechanism of cell death. J. Hazard. Mater. 250, 318-332.

Faisal, M., Saquib, Q., Alatar, A. A., Al-Khedhairy, A. A., Hegazy, A. K., Musarrat, J., 2013. Phytotoxic hazards of NiO-nanoparticles in tomato: a study on mechanism of cell death. J. Hazard. Mater. 250, 318-332.

Feizi, H., Kamali, M., Jafari, L., Moghaddam, P. R., 2013. Phytotoxicity and stimulatory impacts of nanosized and bulk titanium dioxide on fennel (Foeniculum vulgare Mill). Chemosphere. 91, 506-511.

Feizi, H., Moghaddam, P. R., Shahtahmassebi, N., Fotovat, A., 2012. Impact of bulk and nanosized titanium dioxide $\left(\mathrm{TiO}_{2}\right)$ on wheat seed germination and seedling growth. Biol. Trace. Elem. Res. 146, 101-106.

Feng, Q., Zhang, Z., Ma, Y., He, X., Zhao, Y., Chai, Z., 2012. Adsorption and desorption characteristics of arsenic onto ceria nanoparticles. Nanoscale Res. Lett. 7, 1-8.

Feng, Y., Cui, X., He, S., Dong, G., Chen, M., Wang, J., et al., 2013. The role of metal nanoparticles in influencing arbuscular mycorrhizal fungi effects on plant growth. Environ. Sci. Technol. 47, 9496-9504.

French, R. A., Jacobson, A. R., Kim, B., Isley, S. L., Penn, R. L., Baveye, P. C., 2009. Influence of ionic strength, $\mathrm{pH}$, and cation valence on aggregation kinetics of titanium dioxide nanoparticles. Environ. Sci. Technol. 43, 1354-1359. 
Fugetsu, B., Begum, P., 2011. Graphene phytotoxicity in the seedling stage of cabbage, tomato, red spinach, and lettuce. CC BY-NC-SA. (http://www.intechopen.com/books/carbonnanotubes-fromresearch-to-applications/graphene-phytotoxicity-in-the-seedling-stage-ofcabbage-tomato-red-spinach-andlettuce).

Gardea-Torresdey, J. L., Rico, C. M., White, J. C., 2014. Trophic transfer, transformation, and impact of engineered nanomaterials in terrestrial environments. Environ. Sci. Technol. 48, 2526-2540.

Ghosh, M., Bhadra, S., Adegoke, A., Bandyopadhyay, M., Mukherjee, A., 2015. MWCNT uptake in allium cepa root cells induces cytotoxic and genotoxic responses and results in DNA hyper-methylation. Mutat. Res. Fund. Mol. Mech. Mut.774, 49-58.

Ghosh, S., Mashayekhi, H., Pan, B., Bhowmik, P., Xing, B., 2008. Colloidal behavior of aluminum oxide nanoparticles as affected by $\mathrm{pH}$ and natural organic matter. Langmuir. 24, 12385-12391.

Gill, S. S., Tuteja, N., 2010. Reactive oxygen species and antioxidant machinery in abiotic stress tolerance in crop plants. Plant Physiol. Biochem. 48, 909-930.

Goodhead, R. M., Moger, J., Galloway, T. S., Tyler, C. R., 2015. Tracing engineered nanomaterials in biological tissues using coherent anti-stokes Raman scattering (CARS) microscopy-A critical review. Nanotoxicology 1-12.

Gopal, M., Kumar, R., Goswami, A., 2012. Nano-pesticides-a recent approach for pest control. The JPPS. 4, 1-7. 
Gottschalk, F., Lassen, C., Kjoelholt, J., Christensen, F., Nowack, B., 2015. Modeling flows and concentrations of nine engineered nanomaterials in the Danish environment. Int. J. Environ. Res. public health. 12, 5581-5602.

Grillo, R., Rosa, A. H., Fraceto, L. F., 2015. Engineered nanoparticles and organic matter: a review of the state-of-the-art. Chemosphere. 119, 608-619.

Haghighi, M., da Silva, J. A. T., 2014. The effect of carbon nanotubes on the seed germination and seedling growth of four vegetable species. J. Crop. Sci. Biotechnol. 17, 201-208.

Handy, R. D., Cornelis, G., Fernandes, T., Tsyusko, O., Decho, A., Sabo-Attwood, T., et al., 2012. Ecotoxicity test methods for engineered nanomaterials: Practical experiences and recommendations from the bench. Environ. Toxicol. Chem. 31, 15-31

Hernandez-Viezcas, J. A., Castillo-Michel, H., Andrews, J. C., Cotte, M., Rico, C., PeraltaVidea, et al., 2013. In situ synchrotron X-ray fluorescence mapping and speciation of $\mathrm{CeO}_{2}$ and $\mathrm{ZnO}$ nanoparticles in soil cultivated soybean (Glycine max). ACS Nano 7, 1415-1423.

Hernandez-Viezcas, J. A., Castillo-Michel, H., Servin, A. D., Peralta-Videa, J. R., GardeaTorresdey, J. L., 2011. Spectroscopic verification of zinc absorption and distribution in the desert plant Prosopis juliflora-velutina (velvet mesquite) treated with $\mathrm{ZnO}$ nanoparticles. Chem. Eng. J. 170, 346-352.

Hong, F., Yang, F., Liu, C., Gao, Q., Wan, Z., et al., 2005. Influences of nano-TiO2 on the chloroplast aging of spinach under light. Biol. Trace Elem. Res. 104, 249-260. 
Hong, J., Peralta-Videa, J. R., Rico, C., Sahi, S., Viveros, M. N., Bartonjo, J., et al., 2014. Evidence of translocation and physiological impacts of foliar applied $\mathrm{CeO}_{2}$ nanoparticles on cucumber (Cucumis sativus) plants. Environ. Sci. Technol. 48, 4376-4385.

Hou, W. C., BeigzadehMilani, S., Jafvert, C. T., Zepp, R. G., 2014. Photoreactivity of Unfunctionalized Single-wall carbon nanotubes involving hydroxyl radical: chiral dependency and surface coating effect. Environ. Sci. Technol. 48, 3875-3882.

Jaisi, D. P., Elimelech, M., 2009. Single-walled carbon nanotubes exhibit limited transport in soil columns. Environ. Sci. Technol. 43, 9161-9166.

Karunakaran, G., Suriyaprabha, R., Manivasakan, P., Yuvakkumar, R., Rajendran, V., Prabu, P., et al., 2013. Effect of nanosilica and silicon sources on plant growth promoting rhizobacteria, soil nutrients and maize seed germination. Nanobiotechnology, IET, 7, 7077.

Keller, A. A., Fournier, E., Fox, J., 2015. Minimizing impacts of land use change on ecosystem services using multi-criteria heuristic analysis. J. Environ. Manage. 156, 23-30.

Keller, A. A., McFerran, S., Lazareva, A., Suh, S., 2013. Global life cycle releases of engineered nanomaterials. J. Nanopart. Res. 15, 1-17.

Keller, A. A., Wang, H., Zhou, D., Lenihan, H. S., Cherr, G., Cardinale, B. J., et al., 2010. Stability and aggregation of metal oxide nanoparticles in natural aqueous matrices. Environ. Sci. Technol. 44, 1962-1967.

Khodakovskaya, M. V., de Silva, K., Biris, A. S., Dervishi, E., Villagarcia, H., 2012. Carbon nanotubes induce growth enhancement of tobacco cells. ACS Nano 6, 2128-2135. 
Khodakovskaya, M. V., Kim, B. S., Kim, J. N., Alimohammadi, M., Dervishi, E., Mustafa, et al., 2013. Carbon nanotubes as plant growth regulators: effects on tomato growth, reproductive system, and soil microbial community. Small 9, 115-123.

Klaine, S. J., Alvarez, P. J., Batley, G. E., Fernandes, T. F., Handy, R. D., Lyon, D. Y., et al., 2008. Nanomaterials in the environment: behavior, fate, bioavailability, and effects. Environ. Toxicol. Chem. 27, 1825-1851.

Kumari, M., Khan, S. S., Pakrashi, S., Mukherjee, A., \& Chandrasekaran, N., 2011. Cytogenetic and genotoxic effects of zinc oxide nanoparticles on root cells of Allium cepa. J. Hazard. Mater. 190, 613-621.

Kunhikrishnan, A., Shon, H.K., Bolan, N.S., El Saliby, I., Vigneswaran, S., 2015. Sources, distribution, environmental fate, and ecological effects of nanomaterials in wastewater streams. Crit. Rev. Env. Sci. Technol. 45. 277-318.

Larue, C., Veronesi, G., Flank, A. M., Surble, S., Herlin-Boime, N., Carrière, M. (2012). Comparative uptake and impact of $\mathrm{TiO}_{2}$ nanoparticles in wheat and rapeseed. J. Toxicol. Environ. Health. 75, 722-734.

Lee, C.W., Mahendra, S., Zodrow, K., Li, D., Tsai, Y.C., et al., 2010. Developmental phytotoxicity of metal oxide nanoparticles to Arabidopsis thaliana. Environ. Toxicol. Chem. 29, 669-675.

Lee, S., Kim, S., Kim, S., Lee, I., 2013. Assessment of phytotoxicity of ZnO NPs on a medicinal plant, Fagopyrum esculentum. Environ. Sci. Pollut. R. 20, 848-854. 
Levard, C., Hotze, E. M., Lowry, G. V., Brown Jr, G. E., 2012. Environmental transformations of silver nanoparticles: impact on stability and toxicity. Environ. Sci. Technol. 46, 69006914.

Li, K. E., Chang, Z. Y., Shen, C. X., Yao, N., 2015. Toxicity of Nanomaterials to Plants. In Nanotechnology and Plant Sciences. 101-123.

Liang, Y., Bradford, S. A., Simunek, J., Heggen, M., Vereecken, H., Klumpp, E., 2013. Retention and remobilization of stabilized silver nanoparticles in an undisturbed loamy sand soil, Environ. Sci. Technol. 47, 12229-12237.

Liman, R., 2013. Genotoxic effects of Bismuth (III) oxide nanoparticles by allium and comet assay. Chemosphere 93, 269-273.

Lin, D., Liu, N., Yang, K., Zhu, L., Xu, Y., Xing, B., 2009. The effect of ionic strength and pH on the stability of tannic acid-facilitated carbon nanotube suspensions. Carbon. 47, 28752882.

Lin, D., Xing, B., 2007. Phytotoxicity of nanoparticles: inhibition of seed germination and root growth. Environ. Pollut. 150, 243-250.

Lin, S., Reppert, J., Hu, Q., Hudson, J. S., Reid, M. L., Ratnikova, T. A., et al., 2009. Uptake, translocation, and transmission of carbon nanomaterials in rice plants. Small 5, 11281132.

Linkov, I., Bates, M. E., Canis, L. J., Seager, T. P., Keisler, J. M., 2011. A decision-directed approach for prioritizing research into the impact of nanomaterials on the environment and human health. Nat. Nanotechnol. 6, 784-787. 
Liu, F. F., Zhao, J., Wang, S., Du, P., Xing, B., 2014. Effects of solution chemistry on adsorption of selected pharmaceuticals and personal care products (PPCPs) by graphenes and carbon nanotubes. Environ. Sci. Technol. 48, 13197-13206.

Liu, H.H. and Cohen, Y., 2014. Multimedia environmental distribution of engineered nanomaterials. Environ. Sci. Technol. 48, 3281-3292.

Liu, X., Chen, G., Erwin, J. G., Adam, N. K., Su, C., 2013. Release of phosphorous impurity from $\mathrm{TiO}_{2}$ anatase and rutile nanoparticles in aquatic environments and its implications. Water Res. 47, 6149-6156.

Liu, X., O'Carroll, D. M., Petersen, E. J., Huang, Q., Anderson, C. L. 2009. Mobility of multiwalled carbon nanotubes in porous media. Environ. Sci. Technol. 43, 8153-8158.

Liu, X., Ray, J. R., Neil, C. W., Li, Q., Jun, Y. S., 2015. Enhanced colloidal stability of $\mathrm{CeO}_{2}$ nanoparticles by ferrous ions: Adsorption, redox reaction, and surface precipitation. Environ. Sci. Technol. 49, 5476-5483.

López-Moreno, M. L., de la Rosa, G., Hernández-Viezcas, J. Á., Castillo-Michel, H., Botez, C. E., Peralta-Videa, J. R., et al., 2010. Evidence of the differential biotransformation and genotoxicity of $\mathrm{ZnO}$ and $\mathrm{CeO}_{2}$ nanoparticles on soybean (Glycine max) plants. Environ. Sci. Technol. 44, 7315-7320.

Luo, Z., Qiu, Z., Chen, Z., Du Laing, G., Liu, A., Yan, C., 2015. Impact of $\mathrm{TiO}_{2}$ and $\mathrm{ZnO}$ nanoparticles at predicted environmentally relevant concentrations on ammonia-oxidizing bacteria cultures under ammonia oxidation Environ. Sci. Pollut. Res. 22, 2891-2899. 
Luo, Z., Wang, Z., Li, Q., Pan, Q., Yan, C. et al., 2011. Spatial distribution, electron microscopy analysis of titanium and its correlation to heavy metals: Occurrence and sources of titanium nanomaterials in surface sediments from Xiamen Bay, China. J. Environ. Monit.13, 1046-1052.

Lv, J., Zhang, S., Wang, S., Luo, L., Huang, H., Zhang, J., 2014. Chemical transformation of zinc oxide nanoparticles as a result of interaction with hydroxyapatite. Colloids Surf. A. $461,126-132$.

Ma, R., Levard, C., Michel, F. M., Brown Jr, G. E., Lowry, G. V., 2013. Sulfidation mechanism for zinc oxide nanoparticles and the effect of sulfidation on their solubility. Environ. Sci. Technol, 47, 2527-2534.

Ma, X., Geiser-Lee, J., Deng, Y., Kolmakov, A., 2010. Interactions between engineered nanoparticles (ENPs) and plants: phytotoxicity, uptake and accumulation. Sci. Total Environ. 408, 3053-3061.

Ma, Y., He, X., Zhang, P., Zhang, Z., Guo, Z., Tai, R., et al., 2011. Phytotoxicity and biotransformation of $\mathrm{La}_{2} \mathrm{O}_{3}$ nanoparticles in a terrestrial plant cucumber (Cucumis sativus). Nanotoxicology. 5, 743-753.

Mahmoodzadeh, H., Aghili, R., 2014. Effect on germination and early growth characteristics in wheat plants (Triticumaestivum L.) seeds exposed to $\mathrm{TiO}_{2}$ nanoparticles. J Chem Health Risks 4(1), 29-36.

Majumdar, S., Peralta-Videa, J. R., Bandyopadhyay, S., Castillo-Michel, H., Hernandez-Viezcas, J. A., Sahi, S., et al., 2014. Exposure of cerium oxide nanoparticles to kidney bean shows disturbance in the plant defense mechanisms. J. Hazard. Mater. 278, 279-287. 
Majumdar, S., Almeida, I.C., Arigi, E.A., Choi, H., VerBerkmoes, et al., 2015. Environmental effects of nanoceria on seed production of common bean (Phaseolus vulgaris): A proteomic analysis. Environ. Sci. Technol, 49, 13283-13293.

Markus, A. A., Parsons, J. R., Roex, E. W. M., de Voogt, P., Laane, R. W. P. M., 2015. Modeling aggregation and sedimentation of nanoparticles in the aquatic environment. Sci. Total Environ. 506, 323-329.

Mashayekhi, H., Ghosh, S., Du, P., Xing, B., 2012. Effect of natural organic matter on aggregation behavior of $\mathrm{C}_{60}$ fullerene in water. J. Colloid Interface Sci. 374, 111-117.

Mazhoudi, S., Chaoui, A., Ghorbal, M. H., El Ferjani, E., 1997. Response of antioxidant enzymes to excess copper in tomato (Lycopersicon esculentum, Mill.). Plant Sci. 127, 129-137.

McShane, H. V., Sunahara, G. I., Whalen, J. K., Hendershot, W. H., 2014. Differences in soil solution chemistry between soils amended with nanosized $\mathrm{CuO}$ or $\mathrm{Cu}$ reference materials: Implications for nanotoxicity tests. Environ. Sci. Technol. 48, 8135-8142.

Metz, K. M., Mangham, A. N., Bierman, M. J., Jin, S., Hamers, R. J., Pedersen, J. A., 2009. Engineered nanomaterial transformation under oxidative environmental conditions: Development of an in vitro biomimetic assay. Environ. Sci. Technol. 43, 1598-1604.

Mirzajani, F., Askari, H., Hamzelou, S., Schober, Y., Römpp, A., Ghassempour, A., et al., 2014. Proteomics study of silver nanoparticles toxicity on Oryza sativa L. Ecotoxicol. Environ. Saf. $108,335-339$.

Monica, R. C., Cremonini, R., 2009. Nanoparticles and higher plants. Caryologia. 62, 161-165. 
Morales, M. I., Rico, C. M., Hernandez-Viezcas, J. A., Nunez, J. E., Barrios, A. C., Tafoya, A., et al., 2013. Toxicity assessment of cerium oxide nanoparticles in cilantro (Coriandrum sativum L.) plants grown in organic soil. J. Agric. Food Chem. 61, 6224-6230.

Mueller, N. C., Nowack, B., 2008. Exposure modeling of engineered nanoparticles in the environment. Environ. Sci. Technol. 42, 4447-4453.

Mukherjee, A., Peralta-Videa, J. R., Bandyopadhyay, S., Rico, C. M., Zhao, L., GardeaTorresdey, J. L., 2014. Physiological effects of nanoparticulate ZnO in green peas (Pisum sativum L.) cultivated in soil. Metallomics 6, 132-138.

Mukherjee, B., Weaver, J. W., 2010. Aggregation and charge behavior of metallic and nonmetallic nanoparticles in the presence of competing similarly-charged inorganic ions. Environ. Sci. Technol. 44, 3332-3338.

Musante, C.,White, J. C., 2012. Toxicity of silver and copper to Cucurbita pepo: differential effects of nano and bulk-size particles. Environ. Toxicol. 27, 510-517.

Nair, P. M. G., Chung, I. M., 2015. Physiological and molecular level studies on the toxicity of silver nanoparticles in germinating seedlings of mung bean (Vigna radiata L.). Acta. Physiol. Plant. 37, 1-11.

Nair, R., Mohamed, M. S., Gao, W., Maekawa, T., Yoshida, Y., Ajayan, P. M., 2012. Effect of carbon nanomaterials on the germination and growth of rice plants. J. Nanosci. Nanotechnol. 12, 2212-2220. 
Navarro, E., Baun, A., Behra, R., Hartmann, N.B., Filser, J., Miao, et al., 2008. Environmental behavior and ecotoxicity of engineered nanoparticles to algae, plants, and fungi. Ecotoxicology. 17, 372-386.

Ottofuelling, S., Von Der Kammer, F., Hofmann, T., 2011. Commercial titanium dioxide nanoparticles in both natural and synthetic water: comprehensive multidimensional testing and prediction of aggregation behavior. Environ. Sci. Technol. 45, 10045-10052.

Pachapur, V. L., Larios, A. D., Cledón, M., Brar, S. K., Verma, M., Surampalli, R. Y., 2016. Behavior and characterization of titanium dioxide and silver nanoparticles in soils. Sci. Total Environ. doi:10.1016/j.scitotenv.2015.11.090

Parveen, A., Rao, S., 2015. Effect of nanosilver on seed germination and seedling growth in Pennisetum glaucum. J. Cluster Sci. 26, 693-701.

Peralta-Videa, J. R., Zhao, L., Lopez-Moreno, M. L., de la Rosa, G., Hong, J., Gardea-Torresdey, J. L. 2011. Nanomaterials and the environment: a review for the biennium 2008-2010. J. Hazard. Mater. 186, 1-15.

Petosa, A. R., Jaisi, D. P., Quevedo, I. R., Elimelech, M., Tufenkji, N., 2010. Aggregation and deposition of engineered nanomaterials in aquatic environments: role of physicochemical interactions. Environ. Sci. Technol. 44, 6532-6549.

Petrie, B., Barden, R., Kasprzyk-Hordern, B., 2015. A review on emerging contaminants in wastewaters and the environment: current knowledge, understudied areas and recommendations for future monitoring. Water res. 72, 3-27. 
Qi, M., Liu, Y., Li, T., 2013. Nano-TiO 2 improve the photosynthesis of tomato leaves under mild heat stress. Biol. Trace Elem. Res.156, 323-328.

Qu, X., Hwang, Y. S., Alvarez, P. J., Bouchard, D., Li, Q. 2010. UV irradiation and humic acid mediate aggregation of aqueous fullerene $\left(\mathrm{nC}_{60}\right)$ nanoparticles. Environ. Sci. Technol. 44, 7821-7826.

Rathnayake, S., Unrine, J. M., Judy, J., Miller, A. F., Rao, W., Bertsch, P. M. 2014. Multitechnique investigation of the $\mathrm{pH}$ dependence of phosphate induced transformations of $\mathrm{ZnO}$ nanoparticles. Environ. Sci. Technol. 48, 4757-4764.

Rico, C. M., Barrios, A. C., Tan, W., Rubenecia, R., Lee, S. C., Varela-Ramirez, A., et al., 2015. Physiological and biochemical response of soil-grown barley (Hordeum vulgare L.) to cerium oxide nanoparticles. Environ. Sci. Pollut. Res. 22, 10551-10558.

Rico, C. M., Lee, S. C., Rubenecia, R., Mukherjee, A., Hong, J., Peralta-Videa, J. R., et al., 2014. Cerium oxide nanoparticles impact yield and modify nutritional parameters in wheat (Triticum aestivum L.). J. Agric. Food Chem. 62, 9669-9675.

Rico, C.M., Peralta-Videa, J.R., Gardea-Torresdey, J.L. 2015. Chemistry, biochemistry of nanoparticles and their role in antioxidant defense system in plants. In: Siddiqui, M.H., Al-Whaibi, M.H., Mohammed, F. (Eds.), Nanotechnology and Plant SciencesNanoparticles and Their Impact on Plants. Chapter 1 pages 1-17 (doi: 10.1007/978-3319-14502-0_1).

Rico, C. M., Majumdar, S., Duarte-Gardea, M., Peralta-Videa, J. R., Gardea-Torresdey, J. L. 2011. Interaction of nanoparticles with edible plants and their possible implications in the food chain. J. Agric. Food Chem. 59, 3485-3498. 
Rico, C. M., Morales, M. I., Barrios, A. C., McCreary, R., Hong, J., Lee, W. Y., et al., 2013. Effect of cerium oxide nanoparticles on the quality of rice (Oryza sativa L.) grains. J. Agric. Food Chem. 61, 11278-11285.

Rispail, N., De Matteis, L., Santos, R., Miguel, A. S., Custardoy, L., Testillano, P. S., et al., 2014. Quantum dot and superparamagnetic nanoparticle interaction with pathogenic fungi: internalization and toxicity profile. ACS Appl. Mater. Interfaces. 6, 9100-9110.

Robichaud, C. O., Tanzil, D., Weilenmann, U., Wiesner, M. R., 2005. Relative risk analysis of several manufactured nanomaterials: An insurance industry context. Environ. Sci. Technol. 39, 8985-8994.

Rodrigues, D. F., Jaisi, D. P., Elimelech, M., 2012. Toxicity of functionalized single-walled carbon nanotubes on soil microbial communities: implications for nutrient cycling in soil. Environ. Sci. Technol. 47, 625-633.

Santimano, M. C., Kowshik, M., 2013. Altered growth and enzyme expression profile of $\mathrm{ZnO}$ nanoparticles exposed non-target environmentally beneficial bacteria. Environ. Monit. Assess. 185, 7205-7214.

Scheckel, K. G., Luxton, T. P., El Badawy, A. M., Impellitteri, C. A., Tolaymat, T. M., 2010. Synchrotron speciation of silver and zinc oxide nanoparticles aged in a kaolin suspension. Environ. Sci. Technol. 44, 1307-1312.

Servin, A. D., Morales, M. I., Castillo-Michel, H., Hernandez-Viezcas, J. A., Munoz, B., Zhao, L., et al., 2013. Synchrotron verification of $\mathrm{TiO}_{2}$ accumulation in cucumber fruit: a possible pathway of $\mathrm{TiO}_{2}$ nanoparticle transfer from soil into the food chain. Environ. Sci. Technol. 47, 11592-11598. 
Shapira, P., Youtie, J., 2015. The economic contributions of nanotechnology to green and sustainable growth. In Green Processes for Nanotechnology 409-434.

Sharma, P., Jha, A. B., Dubey, R. S.,Pessarakli, M., 2012. Reactive oxygen species, oxidative damage, and antioxidative defense mechanism in plants under stressful conditions. J. of Botany. http://dx.doi.org/10.1155/2012/217037

Shaw, A. K., Hossain. Z., 2013. Impact of nano-CuO stress on rice (Oryza sativa L.) seedlings. Chemosphere 93, 906-915.

Shaymurat, T., Gu, J., Xu, C., Yang, Z., Zhao, Q., Liu, Y., et al., 2012. Phytotoxic and genotoxic effects of $\mathrm{ZnO}$ nanoparticles on garlic (Allium sativum L.): A morphological study. Nanotoxicology 6, 241-248.

Shen, C. X., Zhang, Q. F., Li, J., Bi, F. C., Yao, N., 2010. Induction of programmed cell death in Arabidopsis and rice by single-wall carbon nanotubes. Am. J. Bot. 97, 1602-1609.

Shen, X., Wang, X., Tao, S., Xing, B., 2014. Displacement and competitive sorption of organic pollutants on multiwalled carbon nanotubes. Environ. Sci. Pollut. Res. 21, 11979-11986.

Siddiqui, M. H., Al-Whaibi, M. H., 2014. Role of nano-SiO${ }_{2}$ in germination of tomato (Lycopersicum esculentum seeds Mill.). Saudi. J. Biol. Sci. 21, 13-17.

Suriyaprabha, R., Karunakaran, G., Yuvakkumar, R., Rajendran, V., Kannan, N., 2012. Silica nanoparticles for increased silica availability in maize (Zea mays. L) seeds under hydroponic conditions. Curr. Nanosci. 8, 902-908.

Suzuki, N., Koussevitzky, S., Mittler, R. O. N., Miller, G. A. D., 2012. ROS and redox signalling in the response of plants to abiotic stress. Plant, Cell Environ. 35, 259-270. 
Tan, X., Wang, X., Chen, C., Sun, A., 2007. Effect of soil humic and fulvic acids, pH and ionic strength on $\mathrm{Th}(\mathrm{IV})$ sorption to $\mathrm{TiO}_{2}$ nanoparticles. Appl. Radiat. Isot. 65, 375-381.

Thannickal, V. J., Fanburg, B. L., 2000. Reactive oxygen species in cell signaling. Am. J. Physiol. Lung Cell Mol. Physiol. 279, L1005-L1028.

Theerakarunwong, C., Chouychai, W., 2013. Efficiency of titanium dioxide on mungbean seed sterile and their nanotoxicity to mungbean growth in vitro. Int. J. Agric. Biol. 15, 10391042.

Thuesombat, P., Hannongbua, S., Akasit, S., Chadchawan, S., 2014. Effect of silver nanoparticles on rice (Oryza sativa L. cv. KDML 105) seed germination and seedling growth. Ecotoxicol. Environ. Saf.104, 302-309.

Tiwari, D. K., Dasgupta-Schubert, N., Cendejas, L. V., Villegas, J., Montoya, L. C., García, S. B., 2014. Interfacing carbon nanotubes (CNT) with plants: enhancement of growth, water and ionic nutrient uptake in maize (Zea mays) and implications for nanoagriculture. Appl. Nanosci. 4, 577-591.

Tolaymat, T., El Badawy, A., Sequeira, R., Genaidy, A., 2015. A system-of-systems approach as a broad and integrated paradigm for sustainable engineered nanomaterials. Sci. Total Environ. 511, 595-607.

Tripathi, S., Sarkar, S., 2015. Influence of water soluble carbon dots on the growth of wheat plant. Appl. Nanosci. 5, 609-616.

Tripathi, S., Sonkar, S. K., Sarkar, S., 2011. Growth stimulation of gram (Cicer arietinum) plant by water soluble carbon nanotubes. Nanoscale. 3, 1176-1181. 
Unrine, J. M., Colman, B. P., Bone, A. J., Gondikas, A. P., Matson, C. W., 2012. Biotic and abiotic interactions in aquatic microcosms determine fate and toxicity of $\mathrm{Ag}$ nanoparticles. Part 1. Aggregation and dissolution. Environ. Sci. Technol. 46, 6915-6924.

Vannini, C., Domingo, G., Onelli, E., De Mattia, F., Bruni, I., Marsoni, M., et al., 2014. Phytotoxic and genotoxic effects of silver nanoparticles exposure on germinating wheat seedlings. J. Plant Physiol. 171, 1142-1148.

Wang, C., Bobba, A. D., Attinti, R., Shen, C., Lazouskaya, V., Wang, L. P., et al., 2012. Retention and transport of silica nanoparticles in saturated porous media: effect of concentration and particle size. Environ. Sci. Technol. 46, 7151-7158.

Wang, F., Yao, J., Sun, K., Xing, B., 2010. Adsorption of dialkyl phthalate esters on carbon nanotubes. Environ. Sci. Technol. 44, 6985-6991.

Wang, M. M., Wang, Y. C., Wang, X. N., Liu, Y., Zhang, H., Zhang, J. W., Xu, A., 2015. Mutagenicity of $\mathrm{ZnO}$ nanoparticles in mammalian cells: Role of physicochemical transformations under the aging process. Nanotoxicology 9, 972-982.

Wang, P., Menzies, N. W., Lombi, E., McKenna, B. A., Johannessen, B., Glover, C. J., et al., 2013. Fate of $\mathrm{ZnO}$ nanoparticles in soils and cowpea (Vigna unguiculata). Environ. Sci. Technol. 47, 13822-13830.

Wang, Q., Ma, X., Zhang, W., Pei, H., Chen, Y., 2012. The impact of cerium oxide nanoparticles on tomato (Solanum lycopersicum L.) and its implications for food safety. Metallomics 4, 1105-1112. 
Wang, X., Lu, J., Xu, M., Xing, B., 2008. Sorption of pyrene by regular and nanoscaled metal oxide particles: influence of adsorbed organic matter. Environ. Sci. Technol. 42, 72677272.

Wiesner, M. R., Lowry, G. V., Alvarez, P., Dionysiou, D., Biswas, P., 2006. Assessing the risks of manufactured nanomaterials. Environ. Sci. Technol. 40, 4336-4345.

Xiang, L., Zhao, H. M., Li, Y. W., Huang, X. P., Wu, X. L., Zhai, T., et al., 2015. Effects of the size and morphology of zinc oxide nanoparticles on the germination of Chinese cabbage seeds. Environ. Sci. Pollut. Res. Int. 22, 10452-10462.

Yang, Y., Wang, J., Zhu, H., Colvin, V. L., Alvarez, P. J., 2012. Relative susceptibility and transcriptional response of nitrogen cycling bacteria to quantum dots. Environ. Sci. Technol. 46, 3433-3441.

Yoon, S. J., Kwak, J. I., Lee, W. M., Holden, P. A., An, Y. J., 2014. Zinc oxide nanoparticles delay soybean development: A standard soil microcosm study. Ecotoxicol. Environ. Saf. 100, 131-137.

Zhang, L., Hou, L., Wang, L., Kan, A. T., Chen, W., Tomson, M. B. 2012. Transport of fullerene nanoparticles ( $\mathrm{n}_{60}$ ) in saturated sand and sandy soil: controlling factors and modeling. Environ. Sci. Technol. 46, 7230-7238.

Zhang, L., Wang, L., Zhang, P., Kan, A. T., Chen, W., Tomson, M. B., 2011. Facilitated transport of 2, 2', 5, 5'-polychlorinated biphenyl and phenanthrene by fullerene nanoparticles through sandy soil columns. Environ. Sci. Technol. 45, 1341-1348. 
Zhang, M., Gao, B., Chen, J., Li, Y. 2015. Effects of graphene on seed germination and seedling growth. J. Nanopart. Res. 17, 1-8.

Zhang, P., Ma, Y., Zhang, Z., He, X., Guo, Z., Tai, R., et al., 2012. Comparative toxicity of nanoparticulate/bulk $\mathrm{Yb}_{2} \mathrm{O} 3$ and $\mathrm{YbCl}_{3}$ to cucumber (Cucumis sativus). Environ. Sci. Technol. 46, 1834-1841.

Zhao, X., Liu, R., 2012. Recent progress and perspectives on the toxicity of carbon nanotubes at organism, organ, cell, and bio macromolecule levels. Environ Int. 40, 244-255.

Zhao, L., Peralta-Videa, J. R., Ren, M., Varela-Ramirez, A., Li, C., Hernandez-Viezcas, J. A., et al., 2012. Transport of $\mathrm{Zn}$ in a sandy loam soil treated with $\mathrm{ZnO}$ NPs and uptake by corn plants: Electron microprobe and confocal microscopy studies. Chem. Eng. J. 184, 18.

Zhao, L., Peralta-Videa, J. R., Rico, C. M., Hernandez-Viezcas, J. A., Sun, Y., Niu, G., et al., 2014. $\mathrm{CeO} 2$ and $\mathrm{ZnO}$ nanoparticles change the nutritional qualities of cucumber (Cucumis sativus). J. Agric. Food Chem. 62, 2752-2759.

Zheng, L., Hong, F., Lu, S., Liu, C., 2005. Effect of nano- $\mathrm{TiO}_{2}$ on strength of naturally aged seeds and growth of spinach. Biol. Trace. Elem. Res. 104, 83-91.

Zhou, D., Keller, A. A., 2010. Role of morphology in the aggregation kinetics of ZnO nanoparticles. Water Res. 44, 2948-2956.

Zhu, Z. J., Wang, H., Yan, B., Zheng, H., Jiang, Y., Miranda, O. R., et al., 2012. Effect of surface charge on the uptake and distribution of gold nanoparticles in four plant species. Environ. Sci. Technol. 46, 12391-12398. 
Figure legends

Figure 1. Biotic and abiotic factors contributing for ENMs toxicity towards plants.

Figure 2. Physicochemical properties determining the ENMs toxicity towards living organisms. 
Table 1. Summary of the plant nanotoxicity/studies upon ENMs exposure.

\begin{tabular}{|c|c|c|c|c|c|c|c|c|c|}
\hline ENMs & Size (nm) & Surface area $\left(\mathbf{m}^{2} / \mathbf{g}\right)$ & Shape & Purity (\%) & Concentration & Plant & Effects & $\begin{array}{c}\text { Impact } \\
\text { (positive or } \\
\text { negative) }\end{array}$ & References \\
\hline \multirow[t]{12}{*}{$\mathrm{n}-\mathrm{ZnO}$} & 20 & $50 \pm 10$ & & $>99.5$ & 1600 mg/L & Cucumber & Germination & + & Lin and Xing 2007 \\
\hline & 20 & $50 \pm 10$ & & $>99.5$ & 2000 mg/L & Corn & Plant Growth & - & Lin and Xing 2007 \\
\hline & $<100$ & 5.0 & & 99.5 & $25-100 \mu \mathrm{g} / \mathrm{ml}$ & Onion & Genotoxicity & - & Kumari et al., 2011 \\
\hline & 8 & & Hexagonal & 100 & $2000 \mathrm{mg} / \mathrm{L}$ & Soya Bean & Plant Growth & - & Lopez-Moreno et al., 2010 \\
\hline & $<50$ & & & $>97$ & $500 \mathrm{mg} / \mathrm{kg}$ & Soya Bean & Seeds formation & - & Yoon et al., 2014 \\
\hline & 4 & & Hexagonal & & $50 \mathrm{mg} / \mathrm{L}$ & Garlic & Genotoxicity & - & Shaymurat et al., 2012 \\
\hline & 10 & & & & $500 \mathrm{mg} / \mathrm{L}$ & Desert Plant & Root Length & - & Hernandez et al., 2011 \\
\hline & $<50$ & $>10.8$ & nonspherical & $>97$ & $2000 \mathrm{mg} / \mathrm{L}$ & Buckwheat & Genotoxicity & - & Lee et al., 2013 \\
\hline & 10 & & & & $500 \mathrm{mg} / \mathrm{L}$ & Green Peas & Chlorolphyl/Stress & - & Mukherjee et al., 2014 \\
\hline & 100 & & & & $100-10001000 \mathrm{mg} / \mathrm{L}$ & Rice & Root Length/Formation & - & Boonyanitipong et al., 2011 \\
\hline & 90 & & & & $800 \mathrm{mg} / \mathrm{kg}$ & Maize & Stress & - & Liu et al., 2015 \\
\hline & $30 \& 50$ & & spherical and hexagonal & 9950 & $1-80 \mathrm{mg} / \mathrm{L}$ & Chinese Cabbage & Root and Shoot formation & - & Xiang et al., 2015 \\
\hline \multirow[t]{9}{*}{$\mathrm{n}-\mathrm{TiO}_{2}$} & 21 & 50 & Tetragonal & $>99.5$ & $60 \mathrm{ppm}$ & Fennel & Seed germination & + & Feizi et al., 2013 \\
\hline & 50 & & & & $10-40 \mathrm{mg} / \mathrm{ml}$ & Parsley & $\begin{array}{l}\text { Germination, chlorophyll, } \\
\text { growth }\end{array}$ & + & $\begin{array}{c}\text { Dehkourdi \& Mosavi } \\
2013\end{array}$ \\
\hline & & & & & $0.25-4 \%$ & Spinach & Seed germination & + & Zheng et al., 2005 \\
\hline & 16.04 & & & & $0.05-0.2 \mathrm{~g} / \mathrm{L}$ & Tomato & Photosysnthesis & + & $\begin{array}{c}\text { Qi et al., } 2013 \\
\text { Mahmoodzadeh \& Aghili }\end{array}$ \\
\hline & 30.32 & & & & 1200 ppm & Wheat & Root and Shoot length & + & 2014 \\
\hline & 14 or 25 & & polyhedral & & $0-100 \mathrm{ppm}$ & Wheat & Root and Shoot length & + & Larue et al., 2012 \\
\hline & $27 \pm 4$ & & Semispherical & & $750 \mathrm{mg} / \mathrm{kg}$ & Cucumber & Chlorophyll & + & Servin et al., 2012 \\
\hline & & & & & $0.2-4 \%$ & Zea mayes & Germination & - & Morteza et al., 2014 \\
\hline & $27 \pm 4 \mathrm{~nm}$ & & semispherical & & $750 \mathrm{mg} / \mathrm{kg}$ & Cucumber & Stress & - & Servin et al., 2013 \\
\hline \multirow[t]{6}{*}{$\mathrm{n}-\mathrm{CeO}_{2}$} & $8 \pm 1$ & 93.8 & Rods & 95.14 & $500 \mathrm{mg} / \mathrm{kg}$ & Barley & Biomass & + & Rico et al., 2015 \\
\hline & 7 & & & & 2000 mg/L & Soya Bean & Genotoxicity & - & Lopez-Moreno et al., 2010 \\
\hline & $8 \pm 1$ & 93.8 & & & $20-320 \mathrm{mg} / \mathrm{L}$ & Cucumber & Stress & - & Hong et al., 2014 \\
\hline & $8 \pm 1$ & 93.8 & & & $62.5-500 \mathrm{mg} / \mathrm{L}$ & Rice & Stress & - & Rico et al., 2013 \\
\hline & $8 \pm 1$ & 93.8 & & & $62.5-500 \mathrm{mg} / \mathrm{L}$ & Wheat & Nutrition & - & Rico et al., 2014 \\
\hline & 10 & & & & $400-800 \mathrm{mg} / \mathrm{kg}$ & Cucumber & Nutrition & - & Zhao et al., 2014 \\
\hline \multirow[t]{3}{*}{$\mathrm{n}-\mathrm{Ag}$} & & & & & $50 \mathrm{mg} / \mathrm{L}$ & Pearl millet & Germination & + & Parveen \& Rao 2015 \\
\hline & 10 & & & & $2.5 \mathrm{mg} / \mathrm{Kg}$ & Wheat & Genetic expression & + & Dimpka et al., 2013 \\
\hline & 20 & & & & $1000 \mathrm{ug} / \mathrm{ml}$ & Rice & Seed germination & - & Thuesombat et al., 2014 \\
\hline \multirow[t]{3}{*}{$\mathrm{n}-\mathrm{CuO}$} & $<50$ & & & & 0.5 to $1.5 \mathrm{mM}$ & Rice & Stress & - & Shaw and Hossain 2013 \\
\hline & $<50$ & 45 & spherical & & $>500 \mathrm{ppm}$ & Chick pea and soyabean & Root growth & - & Adhikari et al., 2012 \\
\hline & $<50$ & 29 & & & $100-500 \mathrm{mg}$ & Green peas & ROS and plant growth & - & Nair \& Chung 2015 \\
\hline
\end{tabular}


2000- $4000 \mathrm{mg} / \mathrm{L}$

$\begin{array}{cc}\text { CNTs } & 8-15 \\ & 10-30 \\ 6-9 \\ 6-13 \\ & 1-2\end{array}$

n-Si

20-40

12
50

n-Au

3.5

$\mathrm{NiO}$

23.34

\begin{abstract}
200
\end{abstract}

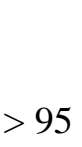

99

90

99.72

spherical

spherical

polyhedral

99.9
$0-40 \mathrm{mg} / \mathrm{L}$

$6.0 \mu \mathrm{g} \mathrm{m} / \mathrm{L}$

$20 \mathrm{mg} / \mathrm{L}$

$80 \mathrm{ug} / \mathrm{ml}$

$100 \mu \mathrm{g} / \mathrm{mL}$

0-1000 mg/L

$5-20 \mathrm{~kg} / \mathrm{ha}$

$8 \mathrm{~g} / \mathrm{L}$

$10 \mathrm{mg} / \mathrm{L}$

tobbaco

$0.025-2.0 \mathrm{mg} / \mathrm{L}$

$500-2000 \mathrm{mg} / \mathrm{L}$
Buckwheat

Genotoxicity

Seed germination

plant growth

Root growth

cell length of root zones

defense

cell damage

spinach

Maize

Tomato

Maize

Growth

Seed weight and

Germination

Seed Germination

Necrosis

Stress, mitochondria, cell damage
Lee et al., 2013

Haghihi and Silva 2014

Tripathi et al., 2011

Tiwari et al., 2014

Wang et al., 2012

Shen et al., 2010

Begum \& Fugestu 2012

Suriyaprabha et al., 2012 Siddiqui \& Al-Whaibai

Karunakaran et al., 2012

Sabo-Attwood et al., 2012

Faisal et al., 2013 


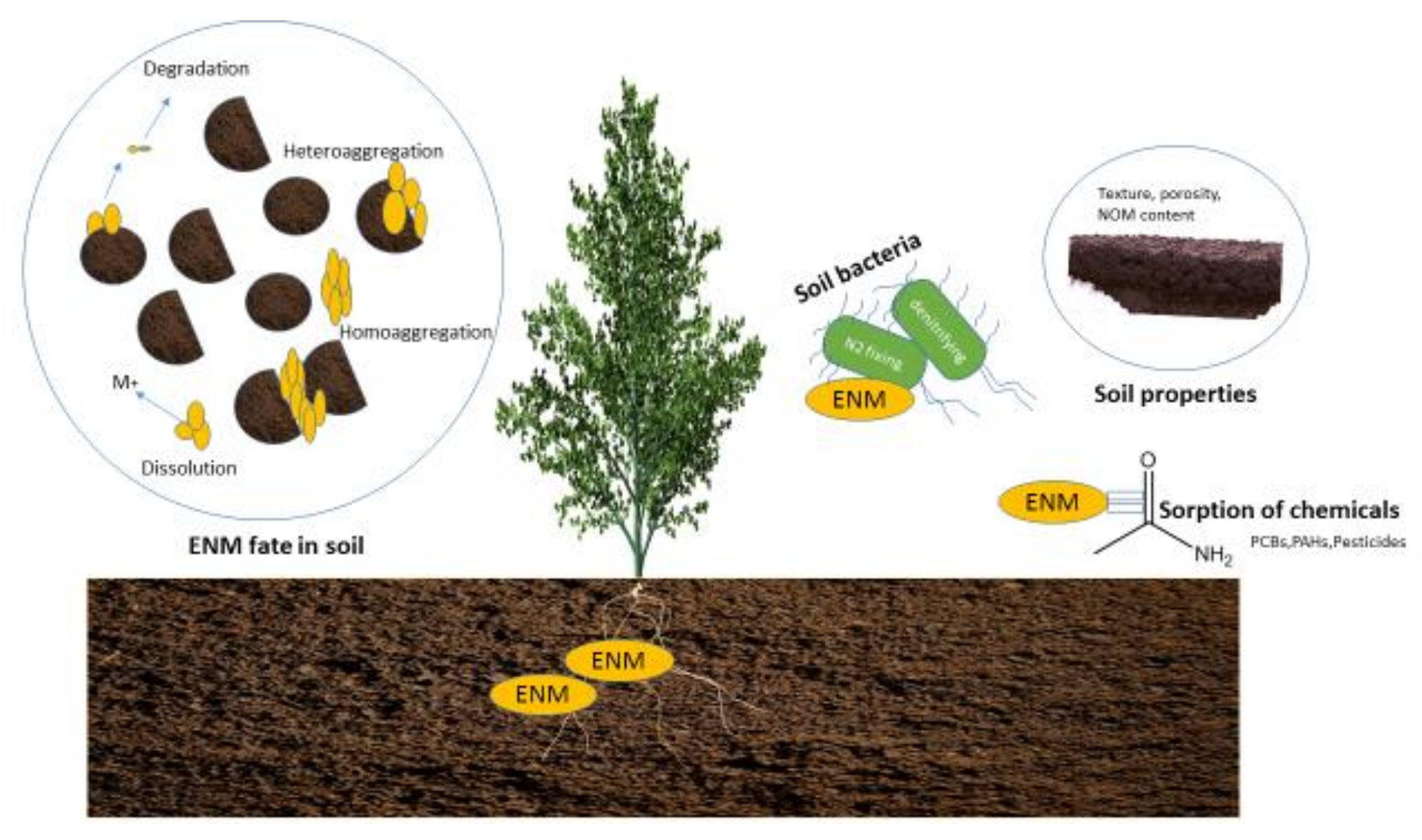

Figure 1. 
Factors affecting ENMs toxicity towards terrestrial plants

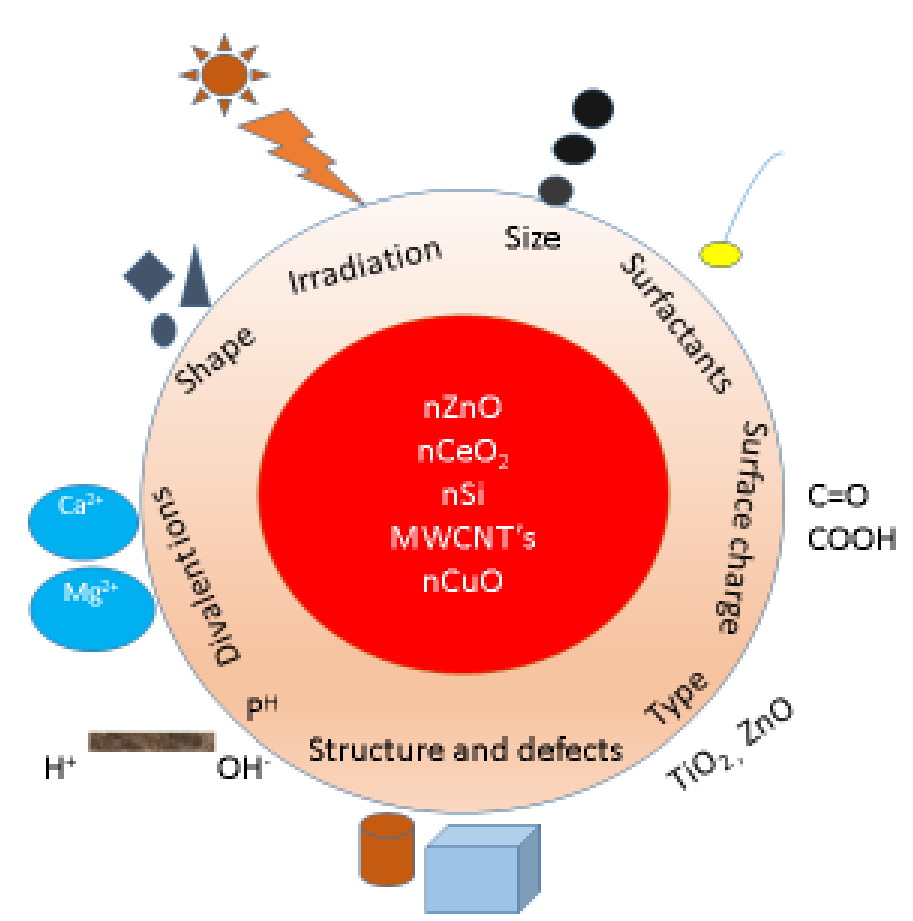

Figure 2. 